\title{
Universities offer animal rights courses
}

Law schools at three US universities, which also house substantial biomedical research programs, are to join a small but growing number of schools around the country offering courses in animal rights. In response to a demand from law students, Harvard, Georgetown and Northwestern University, Chicago, will join the University of California Los Angeles (UCLA), in providing legal tuition in this field.

Membership of the Animal Legal Defense Fund (ALDF), a national organization that is pushing for stricter regulation of laboratory animals under the 1966 Animal Welfare Act, has

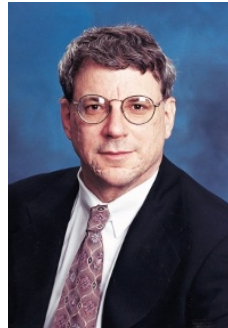

Steven Wise course, which has been running for five years and is also taught by a prominent animal rights campaigner, Tamie Bryant, has seen no campus conflict with the university's biomedical research departments. But Wise is predicting an explosion of cases of the courts uphold the legal standing issue. In addition, he and others say that the rise in cloning and transgenic animal techniques are raising new legal questions.

Wise has already won access to laboratory animal records at the University of Vermont and has been involved with animal rights groups in lawsuits seeking access to such information from other universitives. Wise's over the past 15 years. And the movement was buoyed by ALDF's Supreme Court victory this May in obtaining permission to represent laboratory animalslegal standing-in a case against the US Department of Agriculture (Nature, 400, 197; 1999).

Tutor of the new Harvard course and well-known animal rights lawyer Steven Wise says that activist groups are much better funded and more likely to take to the courts than in the past. In response, more lawyers want to specialize in the field. "Many of our students can expect to face an animal law issue at some point in their careers," admits Harvard's assistant dean for Academic Affairs, Alan Ray.

But will the course also train lawyers inclined to sue biomedical research centers like Harvard someday? UCLA's prejudice, says executive director of the National Association for Biomedical Research Barbara Rich, makes him unsuitable to teach the course: "The issue here is not that the subject shouldn't be taught, what I would be concerned about is balance." However, Wise claims that he simply encourages his student to engage in a "vigorous" debate over whether animals have any legal rights.

As director of Harvard's Animal Resources Center, Arthur Lage oversees the care of the university's lab animals including 58,000 mice, 1,300 rats as well as hamsters, rabbits and guinea pigs. Lage does not feel threatened by the addition of the course to the Harvard curriculum and hopes to sit in on the classes.

\section{Tinker ReAdy, Boston}

\section{Cancer center combines public and private groups}

Italy's largest biomedical research charity, the Italian Association for Cancer Research (AIRC) has announced that it will open a new high-tech cancer research center in Milan at the start of next year.

The IL60 billion (US\$30 million) 7,500 $\mathrm{m}^{2}$ Institute for Molecular Oncology (IFOM) will employ 200 researchers and is to be located on the former Boehringer Mannheim industry research campus. Its novelty lies in the fact that it represents the first time a charity-funded research center has been supported by leading research institutions from both the public and private sector-the University of Milan, the National Institute of Oncology, the European Institute of
Oncology, the Scientific Institute San Raffaele and the Mario Negri institute. Paolo Di Fiore from the European Institute of Oncology, is tipped to head the IFOM.

Italy's scientific community has welcomed the enterprise as a solution to its current public funding crisis, which was accentuated this year when the government suspended its five-year IL30 billion oncology research program at the National Research Council. AIRC has donated IL40 billion annually to cancer research over the past five years, demonstrating the increased activity of the private sector in funding cancer research in Italy.

Martina Ballmaier, Milan
Australia harmonizes bioethics guidelines

Australia has become only the second developed country after Canada to consolidate its approach to ethical conduct of research involving humans in a comprehensive new set of guiding principles agreed by all major players. The 'National Statement on Ethical Conduct of Research Involving Humans' broadens the focus from medical research to encompass disciplines including sociology, anthropology and education, says Don Chalmers, who chairs the health ethics committee within the government's biomedical advisory body, the National Health and Medical Research Council (NHMRC).

The Statement marks the first time that the major research funding organisations have collectively addressed the issue of ethics, bringing together not only the NHMRC but the Australian vice-chancellors committee, the Australian Research Council and the leading national academies.

Chalmers believes the consistency in approach will facilitate multicenter research, which in the past has been hampered by conflicting demands from different ethics committees. The new director of the John Curtin School of Medical Research in Canberra and former chief government medical officer, Judith Whitworth, sees the bid for consistency as a "great benefit" in a climate of "increasing forays by Australians into international collaborative research." Whitworth adds, "The superiority of diverse ethics committees and their individual requirements has been a vexed question, sometimes leading to delays and to some centres having to drop out of multinational studies."

The new guidelines stipulate that if the core ethics committee membership is boosted by extra researchers, the numbers of lay members and outsiders must also be increased in the same proportion.

The document stipulates that ethics committees should comprise a minimum of seven members, two of which must be lay members, and at least one with experience in the area of research being considered, a religious minister and at least one lawyer.

Rada Rouse, Brisbane 